OPEN ACCESS

Edited by:

Amit Awasthi,

Translational Health Science and

Technology Institute, India

Reviewed by:

Silvia Deaglio,

Università degli Studi di Torino, Italy Ashutosh Chaudhry, Memorial Sloan Kettering Cancer

Center, United States

*Correspondence:

Weishan Huang

weishan.huang@cornell.edu;

huang1@/su.edu

Avery August

averyaugust@cornell.edu

Specialty section:

This article was submitted to

T Cell Biology,

a section of the journal

Frontiers in Immunology

Received: 28 February 2018

Accepted: 25 October 2018

Published: 19 November 2018

Citation:

Huang W, Solouki S, Carter C

Zheng S-G and August A (2018) Beyond Type 1 Regulatory T Cells: Co-expression of LAG3 and CD49b in IL-10-Producing T Cell Lineages.

Front. Immunol. 9:2625.

doi: $10.3389 /$ fimmu.2018.02625

\section{Beyond Type 1 Regulatory T Cells: Co-expression of LAG3 and CD49b in IL-10-Producing T Cell Lineages}

\author{
Weishan Huang ${ }^{1,3 *}$, Sabrina Solouki ${ }^{3}$, Chavez Carter ${ }^{3}$, Song-Guo Zheng ${ }^{2}$ and \\ Avery August ${ }^{3 *}$
}

${ }^{1}$ Department of Pathobiological Sciences, School of Veterinary Medicine, Louisiana State University, Baton Rouge, LA, United States, ${ }^{2}$ Department of Medicine, Milton S. Hershey Medical Center, Pennsylvania State University, Hershey, PA, United States, ${ }^{3}$ Department of Microbiology and Immunology, College of Veterinary Medicine, Cornell University, Ithaca, NY, United States

Type 1 regulatory CD4 ${ }^{+} \mathrm{T}(\operatorname{Tr} 1)$ cells express high levels of the immunosuppressive cytokine IL-10 but not the master transcription factor Foxp3, and can suppress inflammation and promote immune tolerance. In order to identify and obtain viable $\operatorname{Tr} 1$ cells for research and clinical applications, co-expression of CD49b and LAG3 has been proposed as a unique surface signature for both human and mouse Tr1 cells. However, recent studies have revealed that this pattern of co-expression is dependent on the stimulating conditions and the differentiation stage of the $\mathrm{CD}^{+}{ }^{+} \mathrm{T}$ cells. Here, using an IL-10 GFP/Foxp3RFP dual reporter transgenic murine model, we demonstrate that co-expression of CD49b and LAG3 is not restricted to the Foxp3 ${ }^{-} \operatorname{Tr} 1$ cells, but is also observed in Foxp3 $3^{+} \mathrm{T}$ regulatory (Treg) cells and $\mathrm{CD} 8^{+} \mathrm{T}$ cells that produce IL-10. Our data indicate that IL-10-producing $\mathrm{Tr} 1$ cells, Treg cells and CD8 ${ }^{+} \mathrm{T}$ cells are all capable of co-expressing LAG3 and CD49b in vitro following differentiation under IL-10-inducing conditions, and in vivo following pathogenic insult or infection in the pulmonary mucosa. Our findings urge caution in the use of LAG3/CD49b co-expression as sole markers to identify $\operatorname{Tr} 1$ cells, since it may mark IL-10-producing $T$ cell lineages more broadly, including the Foxp3 ${ }^{-}$Tr1 cells, Foxp3 ${ }^{+}$Treg cells, and $\mathrm{CD}^{+}{ }^{+}$T cells.

\section{Keywords: IL-10, Foxp3, T cell, parasitic infection, house dust mite, influenza infection, farmer's lung disease, lung} inflammation

\section{INTRODUCTION}

The mammalian immune system has evolved both effector and regulatory immune axes to protect the host from invading pathogens, along with a control mechanism to tune the level of immune reactivity against self- and non-self- agents to prevent host tissue damage. Interleukin-10 (IL-10) is a regulatory cytokine with a demonstrated anti-inflammatory function and plays an essential role in preventing allergic inflammation (1), autoimmunity (2), and pathogen-induced immunopathology $(3,4)$, but can also promote the establishment and maintenance of chronic infection $(5,6)$. IL10 has been reported as a product of activation of multiple immune cell lineages. Innate immune cells including dendritic cells (DCs) (7), macrophages (8), neutrophils (9), and innate lymphoid cells (ILCs) (10) have been reported to express IL-10 in vivo and in vitro. IL-10 is also expressed 
by many cell subsets of the adaptive immune system, including $\mathrm{B}$ cells (11) and T cells comprising the Foxp $3^{-} \mathrm{CD} 4^{+}$(12), Foxp $^{+}$Treg (13), and CD8 ${ }^{+} \mathrm{T}$ cell subsets (14). Regulatory $\mathrm{T}$ cells are defined by their immunosuppressive function, and the three aforementioned subsets of IL-10-producing $\mathrm{T}$ cells have been reported as phenotypically distinct regulatory $\mathrm{T}$ cell subsets, playing important roles in promoting immune tolerance and/or suppressing inflammation in both mouse and human (15-20).

Among the IL-10-producing $\mathrm{T}$ cells, the Foxp $3^{-} \mathrm{CD} 4^{+} \mathrm{T}$ cell subset, also known as type 1 regulatory $\mathrm{T}$ cells ( $\operatorname{Tr} 1$ cells), are inducible in the periphery and have a pivotal role in limiting inflammation (15,21-23). Tr1 cells have been shown to prevent allergic asthma (24) and atopic dermatitis (25) in murine models. In both mouse models and humans, induction of tolerance via specific antigen immunotherapy (SIT) is accompanied by induction of $\operatorname{Tr} 1$ cells $(26,27)$. Therefore, $\operatorname{Tr} 1$ cells have strong promise as a potential therapeutic approach for inflammatory diseases. $\mathrm{Tr} 1$ cells can be differentiated from naïve $\mathrm{CD} 4^{+} \mathrm{T}$ cells upon TCR engagement in the presence of IL-27 in vitro (28), and in order to identify and obtain viable Tr1 cells for clinical application, co-expression of LAG3 and CD49b has been recently proposed to be a cell surface signature of the Foxp $3^{-}$IL-10 high Tr1 cells (15). LAG3 is a structural homolog of the CD4 molecule and can bind to MHC class II with high affinity $(29,30)$. LAG3 is highly expressed by $\mathrm{IL}-10^{+} \mathrm{CD} 4^{+} \mathrm{T}$ cells $(31)$, as well as by activated effector T cells (32) and Foxp $3^{+}$Treg cells (33). CD49b is the $\alpha 2$ integrin subunit, highly expressed by NK cells (34). $\mathrm{CD} 49 \mathrm{~b}$ is up-regulated in T cells that may produce IL-10 and/or pro-inflammatory cytokines (35-37). In addition to Foxp3 $3^{-} \operatorname{Tr} 1$ cells, IL-10 can be highly up-regulated in activated Foxp $3^{+}$Treg and $\mathrm{CD} 8^{+} \mathrm{T}$ cells under inflammatory conditions and/or upon TCR activation. Given the importance of being able to identify Foxp $3^{-} \operatorname{Tr} 1$ cells, including under clinical conditions, and to gain a better understanding of the selectivity of co-expression of LAG3 and CD49b as a cell surface signature for IL-10-producing cells, we sought to determine whether co-expression of LAG3 and $\mathrm{CD} 49 \mathrm{~b}$ can mark a broader range of $\mathrm{T}$ cell subsets that are actively producing high levels of IL-10.

Using a murine model carrying an $\mathrm{IL}-10^{\mathrm{GFP}} / \mathrm{Foxp} 3^{\mathrm{RFP}}$ dual reporter system, we find that co-expression of LAG3 and $\mathrm{CD} 49 \mathrm{~b}$ is a generic feature of the IL-10-producing Foxp $^{-} \mathrm{CD}^{+}$, Foxp $3^{+} \mathrm{CD} 4^{+}$, and $\mathrm{CD}^{+} \mathrm{T}$ cell subsets. The capacity of co-expression of LAG3 and CD49b in marking IL-10 ${ }^{\text {high }} \mathrm{T}$ cell subsets is dependent on the disease conditions and anatomical location of the cells. Furthermore, co-expression of LAG3 and CD49b is also a shared feature of human IL-10-producing FOXP3 ${ }^{-} \mathrm{CD}^{+}$, $\mathrm{FOXP}^{+}{ }^{+} \mathrm{CD}^{+}$, and $\mathrm{CD}^{+}{ }^{+} \mathrm{T}$ cell subsets. Our data reveal that co-expression of LAG3 and CD49b is a generic signature of IL-10-producing $\mathrm{T}$ cells, which is broader than previously appreciated.

Abbreviations: $\mathrm{Nb}$, Nippostrongylus brasiliensis; $\mathrm{Tr} 1$ cell, Type 1 regulatory $\mathrm{T}$ $\left(\mathrm{CD}^{+}{ }^{+} \mathrm{TCR} \beta^{+} \mathrm{Foxp}^{-}{ }^{-} \mathrm{IL}-10^{+}\right)$cell; Treg cell, Foxp3-expressing regulatory T cell; HDM, house dust mite; SR, Saccharopolyspora rectivirgula; WSN, Influenza A/WSN/1933 (H1N1).

\section{MATERIALS AND METHODS}

\section{Mice and Human Blood Samples}

All mice were on the C57BL/6 background. Rag1-/- (B6.129S7Rag1 $\left.{ }^{\text {tm } 1 M o m} / \mathrm{J}\right), \quad$ IL-10 ${ }^{\mathrm{GFP}}$ (B6(Cg)-Illo ${ }^{\text {tm } 1.1 \text { Karp } / J) ~(38), ~ a n d ~}$ Foxp3 ${ }^{\text {RFP }}\left(\mathrm{C} 57 \mathrm{BL} / 6-\right.$ Foxp $\left.3^{\text {tm } 1 F l v} / \mathrm{J}\right)$ (39) reporter mice were from the Jackson Laboratory (Bar Harbor, ME). Single reporter strains were crossed to generate an IL- $10^{\mathrm{GFP}} / \mathrm{Foxp} 3^{\mathrm{RFP}}$ dual reporter strain as we recently reported (40). Human peripheral blood samples were procured from the New York Blood Center collected from healthy cohorts. All experiments were approved by the Office of Research Protection's Institutional Animal Care and Use Committee and Institutional Review Board at Cornell University.

\section{Antibodies and Other Reagents}

All fluorescent antibodies are listed in "fluorochrome-target (clone; annotation if desirable)" format below.

\section{Mouse Antibodies}

Purified anti-CD16/32 (93; Fc block), CD3 $\varepsilon$ (145-2C11), CD28 (37.51), IFN- $\gamma$ (XMG1.2), and IL-12 (C17.8) antibodies were from BioLegend (San Diego, CA); Pacific Blue-CD90 (532.1), FITC-TCR $\beta$ (H57-597), APC-LAG3 (C9B7W), PE-Cy7$\mathrm{CD} 49 \mathrm{~b}(\mathrm{HM} \alpha 2)$, and PE-Cy7-CD62L (MEL-14) were from BioLegend; eFluor 450-CD4 (GK1.5); Alexa Fluor 700-CD4 (GK1.5) were from eBioscience; BD Horizon V500-CD44 (IM7), PE-CD44 (IM7), and APC-Cy7- TCR $\beta$ (H57-597) were from BD Biosciences; PerCP-Cy5.5-CD8 $\alpha$ (2.43) was from Tonbo Biosciences.

\section{Human Antibodies}

Purified anti-CD3e (OTK3) and CD28 (28.2), eFluor 450-CD8 $\alpha$ (RPA-T8) FITC-CD4 (OKT4), and APC-FOXP3 (236A/E7) were from eBioscience; PE-IL-10 (JES3-19F1), Alexa Fluor 647LAG3 (11C3C65), and PerCP-Cy5.5-LAG3 (11C3C65) were from BioLegend; FITC-CD49b (AK-7) and Alexa Fluor 700-CD4 (RPA-T4) were from BD Biosciences.

\section{Other Reagents}

Human TruStain FcX (Fc receptor blocking solution) was from Biolegend; cell fixable viability dye eFluor 506 was from eBiosciences.

\section{Cell Isolation From Various Organs}

Cells from various organs were isolated as we recently described (40). Briefly: blood cells were collected through cardiac puncture, and red blood cells were lysed before analysis; lungs were minced and digested in $0.2 \mathrm{mg} / \mathrm{ml}$ Liberase TL (Sigma, St. Luis, MO) in $37^{\circ} \mathrm{C}$ for $15-30 \mathrm{~min}$, then filtered and red blood cells were lysed before analysis; intestines were flushed, opened longitudinally, and inner contents removed with the blunt end of scissors, then cut into $0.5-\mathrm{cm}$ fragments, followed by digestion in 100 $\mathrm{U} / \mathrm{ml}$ collagenase VIII (Sigma) in $37^{\circ} \mathrm{C}$ for $1 \mathrm{~h}$, filtered, and lymphocytes isolated using gradient separation by $40 \%$ and $80 \%$ Percoll (GE Healthcare, Wilkes-Barre, PA) solutions; perigonadal adipose tissues were minced and digested in $500 \mathrm{U} / \mathrm{ml}$ collagenase I (Worthington Biochemical Corp., Lakewood, NJ) in $37^{\circ} \mathrm{C}$ for 
$30 \mathrm{~min}$, filtered and red blood cells were lysed before analysis. 50$150 \mathrm{U} / \mathrm{ml}$ DNase I (Sigma) were added during digestion to reduce cell death triggered by free DNA.

\section{In vivo Induction of IL-10-Producing T Cells by TCR Activation}

Foxp $3^{\text {RFP }}$ IL-10 ${ }^{\text {GFP }}$ dual reporter mice were injected with 15 $\mu \mathrm{g} /$ mouse anti-CD3 $\varepsilon(145-2 \mathrm{C} 11)$ intraperitoneally on day 0 and 2 , and analyzed on day 4 , as previously described (23).

\section{Nippostrongylus brasiliensis ( $\mathrm{Nb}$ ) Infection}

Mice were given $500 \mathrm{~L} 3 \mathrm{Nb}$ larvae per mouse through subcutaneous injection, as we previously described (40). Cells from the lungs were analyzed 7 days post infection (7 dpi).

\section{House Dust Mite (HDM)-Induced Allergic Disease Model}

Mice were given daily intranasal exposures of $10 \mu \mathrm{g}$ house dust mite (Dermatophagoides pteronyssinus) protein extract (XPB82D3A2.5 from Greer) in PBS, for 10 consecutive days. Cells from the lungs were analyzed $24 \mathrm{~h}$ post the last treatment.

\section{Farmer's Lung Disease (Hypersensitivity Pneumonitis) Model}

Mice were intranasally exposed to $150 \mu \mathrm{g}$ Saccharopolyspora rectivirgula (SR, ATCC 29034) extract on 3 consecutive days each week as previously described (41), for 4 weeks. Cells from the lungs were analyzed on the last day of the fourth week.

\section{Influenza A/WSN/1933 (WSN) Infection}

Mice were intranasally infected with $1 \mathrm{LD}_{50}\left(10^{4} \mathrm{PFU}\right) \mathrm{WSN}$ per mouse, as we previously described (40). Cells from the lungs were analyzed 7 days post infection (7 dpi).

\section{Differentiation of IL-10-Producing T Cells Mouse}

TCR $\beta^{+}$Foxp $3^{\text {RFP }-}$ CD $44^{-} \mathrm{CD}^{2} 2 \mathrm{~L}^{+}$splenic naïve $\mathrm{T}$ cells were sorted on BD FACS Aria II or Fusion systems (BD Biosciences, San Jose, CA), then cultured with Mitomycin-C (Sigma, $50 \mu \mathrm{g} / \mathrm{ml}$ ) treated antigen-presenting cells (APCs; $\mathrm{Rag}^{-/-}$ splenocytes) at 1:2 ratio in the presence of anti-CD3 $\varepsilon(1 \mu \mathrm{g} / \mathrm{mL})$, anti-CD28 $(1 \mu \mathrm{g} / \mathrm{mL})$, recombinant murine (rm) IL-27 (R\&D Systems, $20-25 \mathrm{ng} / \mathrm{ml})$, anti-IFN- $\gamma$ and anti-IL-12 $(10 \mu \mathrm{g} / \mathrm{mL})$ for 3 days.

\section{Human}

Human peripheral blood mononuclear cells (PBMCs) were isolated from blood (New York Blood Center, Long Island, NY) using gradient separation in Ficoll-Paque PLUS (GE Healthcare). PBMCs were cultured in full RPMI-1640 medium for $30 \mathrm{~min}$ in $37^{\circ} \mathrm{C}$, then non-adherent cells were used to enrich for $\mathrm{CD} 4^{+} \mathrm{T}$ cells using anti-human CD4 microbeads (Miltenyl Biotec, San Diego, CA) or $\mathrm{CD}^{+} \mathrm{T}$ cells using a human CD8 isolation kit (BioLegend). Adherent cells were treated with MitomycinC (Sigma, $50 \mu \mathrm{g} / \mathrm{ml}$ ) in $37^{\circ} \mathrm{C}$ for $30 \mathrm{~min}$ and used as APCs. Anti-human CD3e $(1 \mu \mathrm{g} / \mathrm{ml})$ and CD28 (CD28.2, eBioscience, 1$3 \mu \mathrm{g} / \mathrm{ml}$ ), recombinant human (rh) IL-2 (PeproTech, $200 \mathrm{U} / \mathrm{ml}$ ),
IL-10 (PeproTech, 100 U/ml), IL-27 (R\&D System, 25 ng/ml), and IFN- $\alpha 2 \mathrm{~b}$ (R\&D System, $10 \mathrm{ng} / \mathrm{ml}$ ) were added to differentiate human IL-10-producing $\mathrm{T}$ cells. Three days after cultures were set up, cells were stimulated with PMA $(100 \mathrm{ng} / \mathrm{ml}$, SigmaAldrich), Ionomycin (0.5 $\mu \mathrm{M}$, Sigma), Brefeldin A $(5 \mu \mathrm{g} / \mathrm{ml})$, and GolgiStop $(0.5 \mu \mathrm{l} / \mathrm{ml}, \mathrm{BD}$ Biosciences $)$ for $4 \mathrm{~h}$ as we previously described (42), and subjected to surface staining and intracellular staining (see details below).

\section{Flow Cytometry}

Surface staining of live cells were done in the presence of Fc block and fixable viability dye. To detect human CD4 in activated T cells, anti-CD4 antibody was added into the intracellular staining panel. For intracellular cytokine staining, cells were fixed with 2\% paraformaldehyde (Electron Microscopy Sciences, Hatfield, $\mathrm{PA}$ ), permeabilized and stained with anti-cytokine antibodies in $\mathrm{PBS} / 0.2 \%$ saponin (Sigma). Staining for human transcription factor FOXP3 was performed with a Foxp3 staining buffer kit (eBioscience). Flow cytometry data were acquired on LSRII, FACS Aria II or Fusion systems (BD Biosciences), and analyzed in FlowJo (Tree Star, Ashland, OR). All analyses were performed on fixable viability dye negative singlet population.

\section{Statistical Analysis}

Non-parametric Mann-Whitney tests and one-way ANOVA were performed using GraphPad Prism v5.00 (GraphPad, San Diego, $\mathrm{CA}$ ), with $p \leq 0.05$ considered statistically significant. "NS" refers to "No Significance."

\section{RESULTS}

\section{Co-expression of LAG3 and CD49b Marks Both IL-10-Producing CD4 ${ }^{+}$and $\mathrm{CD}^{+}{ }^{+}$ Cells}

LAG3 and CD49b co-expression was previously reported to be a cell surface signature for both mouse and human IL10-producing $\mathrm{CD}^{+} \mathrm{T}$ cells that lack the expression of Foxp3 (also known as type 1 regulatory $\mathrm{T}$ cells, $\operatorname{Tr} 1$ cells) (15). We and others have previously reported that co-culturing murine naive $\mathrm{CD}^{+} \mathrm{T}$ cells with antigen presenting cells (APCs) in the presence of anti-CD3, anti-CD28, anti-IFN- $\gamma$, anti-IL-12, and IL-27 can efficiently induce the differentiation of $\operatorname{Tr} 1$ cells (28, 40, 43), which express high levels of LAG3 and CD49b. Our recent data also demonstrated that this protocol can induce IL-10 production in bulk $\mathrm{T}$ cell populations that include both $\mathrm{CD}^{+}{ }^{+}$and $\mathrm{CD}^{+} \mathrm{T}$ cells (Figure 1A). Surprisingly, the resultant IL-10-producing $\mathrm{CD}^{+} \mathrm{T}$ cells induced in vitro through this protocol also exhibited high levels of LAG3/CD49b co-expression (Figure 1A, last plot). In fact, IL-10-producing $\mathrm{CD} 8^{+} \mathrm{T}$ cells can express higher levels of LAG3 and CD49b than their IL-10producing $\mathrm{CD}^{+}$counterparts induced in the same cell culture (Figure 1B). These data suggest that co-expression of LAG3 and CD 49b is not an exclusive cell surface signature of the Tr1 cells, and may be a shared feature of both IL-10-producing $\mathrm{CD}^{+}$and $\mathrm{CD}^{+} \mathrm{T}$ cells. 

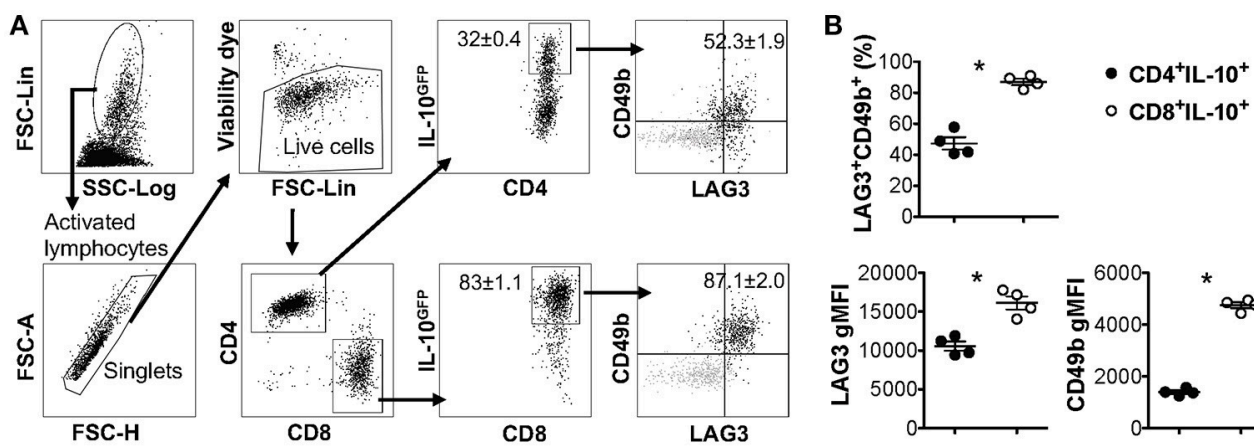

- $\mathrm{CD}^{+} \mathrm{IL}-10^{+}$

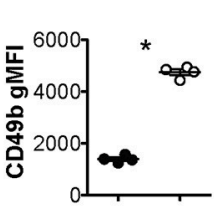

FIGURE 1 | IL-10-producing LAG3 ${ }^{+} \mathrm{CD}_{49} \mathrm{~b}^{+}$T cells include both $\mathrm{CD} 4^{+}$and $\mathrm{CD} 8^{+}$subsets. All experiments were performed with cells carrying the IL-10GFP reporter system for live cell analysis. Naïve T cells were cultured under IL-10-inducing conditions for 3 days. (A) Gating strategy to identify IL-10-expressing CD4+ and

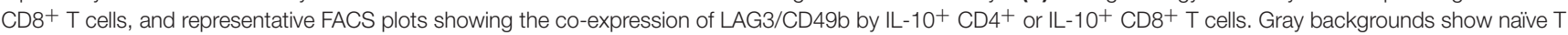
cells as negative control for $L A G 3 / C D 49 b$ quadrant gating. (B) Summary of percentage of LAG3/CD49b double positive population and geometric mean fluorescence intensity (gMFI) of LAG3 and CD49b in IL-10-producing CD4 ${ }^{+}$and CD8 ${ }^{+}$T cells. $N=4$. Data represent results of more than three experiments. ${ }^{*} p \leq 0.05$, by non-parametric Mann-Whitney test. Data presented as Mean \pm S.E.M.

\section{Co-expression of LAG3 and CD49b Marks Both IL-10-Producing Tr1 and Treg Cells}

IL-10 production can be significantly elevated in the pulmonary mucosa during the late stages of parasitic infection by Nippostrongylus brasiliensis $(\mathrm{Nb})$, predominantly by $\mathrm{CD}^{+} \mathrm{T}$ cells that are LAG3/CD49b double positive $(15,44)$. We recently observed that both Foxp $3^{-}$and Foxp $3^{+} \mathrm{T}$ cells are capable of producing IL-10 in the pulmonary tissues post $\mathrm{Nb}$ infection (40). To determine whether co-expression of LAG3 and CD49b is exclusive to Foxp3 ${ }^{-} \operatorname{Tr} 1$ cell subset, we infected IL- $10^{\mathrm{GFP}} / \mathrm{Foxp}^{\mathrm{RFP}}$ dual reporter mice with $\mathrm{Nb}$, and analyzed the IL-10-producing $\mathrm{T}$ cells. We found that, as previously described, a large majority of the IL-10-producing $\mathrm{T}$ cells in the lungs of $\mathrm{Nb}$-infected mice express high levels of both LAG3 and CD49b (Figures 2A,B), and are predominantly $\mathrm{CD}^{+}{ }^{+} \mathrm{T}$ cells (Figure 2C). However, interestingly, these IL10-producing $\mathrm{LAG}^{+} \mathrm{CD}^{+} 9 \mathrm{~b}^{+} \mathrm{CD}^{+} \mathrm{T}$ cells included both Foxp $^{+}$and Foxp3 $3^{-} \mathrm{CD}^{+} \mathrm{T}$ cells subsets (Figure 2C, last plot; and Figure 2D). To further determine whether LAG3/CD49b co-expression is correlated with IL-10 and/or Foxp3 expression in CD4 ${ }^{+} \mathrm{T}$ cells, we compared the percentage of LAG3/CD49b double positive populations in Foxp3 $3^{-} \mathrm{IL}-10^{-}$, Foxp $3^{-}$IL- $10^{+}$, Foxp $^{+}$IL- $10^{-}$, and Foxp $3^{+}$IL- $10^{+}$CD $4^{+}$T cells isolated from the lungs of $\mathrm{Nb}$-infected mice. We found that regardless of expression of Foxp3, $\mathrm{Nb}$ infection did not lead to significant up-regulation of LAG3/CD49b co-expression on IL-10 ${ }^{-} \mathrm{CD}^{+} \mathrm{T}$ cells (Figures 2E,F). However, the percentage of the $\mathrm{LAG}^{+} \mathrm{CD} 49 \mathrm{~b}^{+}$population of $\mathrm{IL}-10^{+} \mathrm{CD} 4^{+} \mathrm{T}$ cells is significantly higher than their IL-10- ${ }^{-}$counterparts (Figure 2F). Moreover, the levels of LAG3 and CD49b expression are similar between the Foxp $3^{+}$and Foxp $3^{-}$counterparts of IL- $10^{+} \mathrm{CD}^{+}$ $\mathrm{T}$ cells (Figure 2G). Therefore, IL-10-producing $\mathrm{CD}^{+} \mathrm{T}$ cells, regardless of Foxp3 expression, have a high capacity of coexpressing LAG3 and CD49b. Together with the data shown in Figure 1, these data suggest that co-expression of LAG3 and $\mathrm{CD} 49 \mathrm{~b}$ is a generic feature of IL-10-producing T cells, including Foxp3 ${ }^{-}$Tr1 cells, Foxp3 ${ }^{+}$Treg cells and CD8 ${ }^{+} \mathrm{T}$ cells.

\section{The Composition of LAG3 ${ }^{+}{\text {CD } 49 b^{+}}^{+}$ IL-10-Producing T Cells Differs in Different Disease Models}

IL-10 plays an essential role in pulmonary inflammatory diseases, which has been reported in multiple murine models of lung disease, including allergic asthma (45), hypersensitivity pneumonitis (HP) (46) and influenza pneumonia (20). We examined whether the expression of LAG3 and CD49b would differ based on the inflammatory response in three mouse models of lung inflammation. Mice carrying the IL- $10^{\mathrm{GFP}} / \mathrm{Foxp} 3^{\mathrm{RFP}}$ dual reporters were exposed intranasally to house dust mite (HDM) protein extract (as a model of allergic asthma), Saccharopolyspora rectivirgula (SR) (as a model of $\mathrm{HP} /$ farmer's lung disease), or infected intranasally with WSN/flu virus (as a model of influenza infection). We observed significant percentages of IL10 -producing $\mathrm{T}$ cells in the lung tissue of mice exposed to HDM (Figure 3A), SR (Figure 3C), or WSN/flu virus (Figure 3E). These IL-10-producing $\mathrm{T}$ cells all co-expressed high levels of LAG3 and CD49b, and include Foxp3 ${ }^{+} \mathrm{CD}^{+}$, Foxp3 ${ }^{-} \mathrm{CD}^{-}$, and $\mathrm{CD}^{+}$subsets in all disease models analyzed (Figure 3 ). However, the relative proportions of IL-10-producing Foxp $3^{+}$ $\mathrm{CD}^{+}{ }^{+}, \mathrm{Foxp}^{-} \mathrm{CD}^{-}$, and $\mathrm{CD} 8^{+}$subsets differed in the various disease models (Figure 3). In contrast to the composition of IL10 -producing $\mathrm{LAG}^{+} \mathrm{CD} 49 \mathrm{~b}^{+} \mathrm{T}$ cells induced by $\mathrm{Nb}$ infection, in which the Foxp3 ${ }^{-} \mathrm{CD}^{+}$subset is the majority $(72 \%$ in Figure 2D), in HDM-induced allergic asthma model, the largest subset of the IL-10-producing $\mathrm{LAG}^{+}{ }^{+} \mathrm{CD} 49 \mathrm{~b}^{+} \mathrm{T}$ cells in the lungs are Foxp $3^{+} \mathrm{CD}^{+} \mathrm{T}$ cells $(60 \%)$, followed by Foxp3 ${ }^{-}$ $\mathrm{CD}^{+} \mathrm{T}$ cells $(32 \%)$, while $\mathrm{CD}^{+} \mathrm{T}$ cells are only around $1.4 \%$ (Figure 3B). In the SR-triggered farmer's lung disease model, Foxp $3^{+} \mathrm{CD}^{+} \mathrm{T}$ cells are the majority of the IL-10producing $\mathrm{LAG}^{+} \mathrm{CD}_{4} 9 \mathrm{~b}^{+} \mathrm{T}$ cell subset in the lungs, however, there are similar percentages of Foxp $3^{-} \mathrm{CD} 4^{+}$and $\mathrm{CD}^{+} \mathrm{T}$ cells (16\% each) (Figure 3D). Strikingly in the murine model of influenza infection, $\mathrm{CD} 8^{+} \mathrm{T}$ cells are the largest subset of the IL-10-producing $\mathrm{LAG}^{+}{ }^{+} \mathrm{CD} 49 \mathrm{~b}^{+} \mathrm{T}$ cells in the lungs $(86 \%)$, 

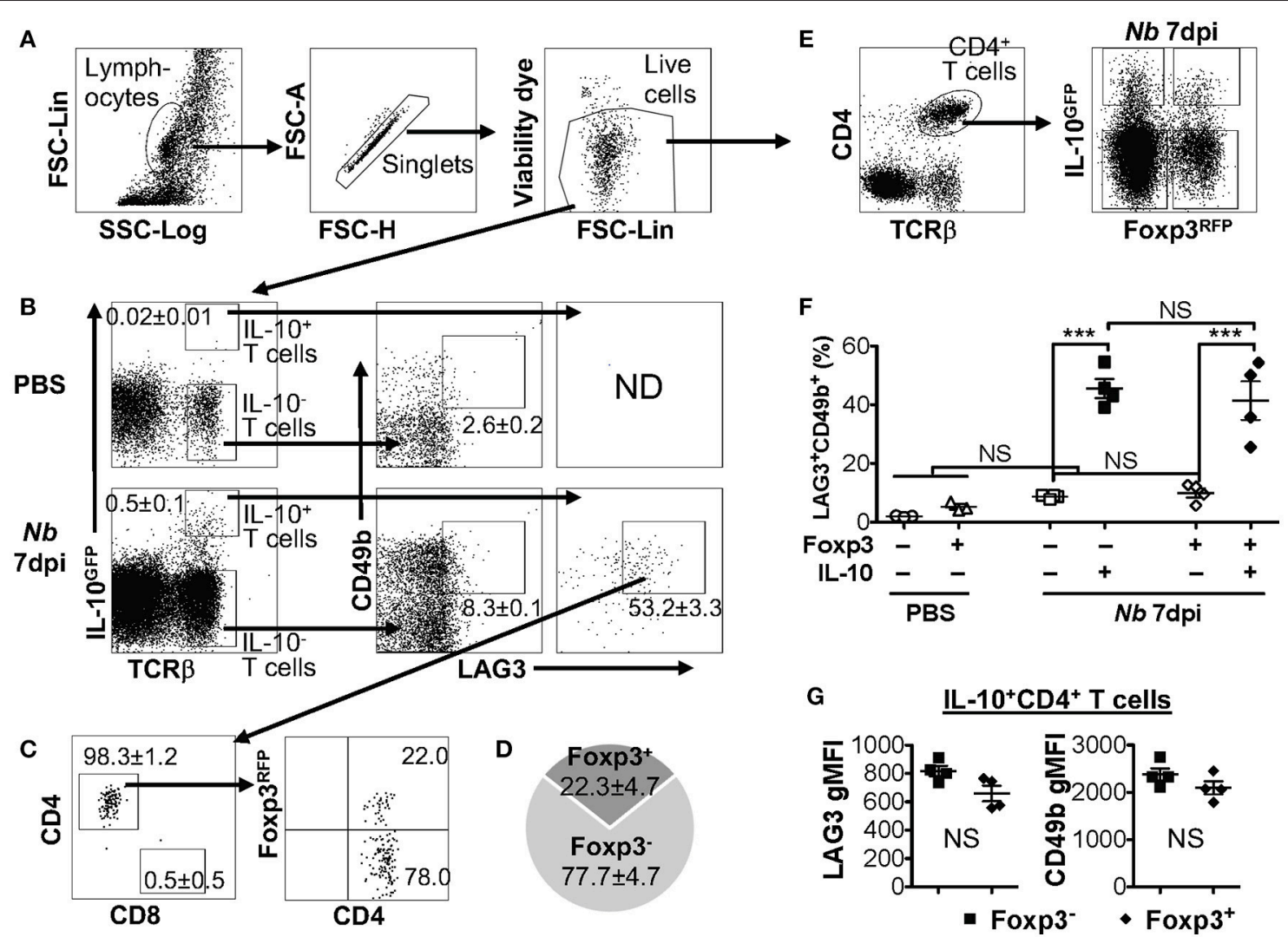

FIGURE 2 | IL-10-producing LAG3 ${ }^{+}$CD49b ${ }^{+}$CD4 ${ }^{+}$T cells include both Foxp3 ${ }^{+}$and Foxp3 ${ }^{-}$subsets. Mice carrying the IL-10GFP/Foxp3RFP dual reporter system were infected with 500 L3 Nippostrongylus brasiliensis (Nb) (or PBS as control) and lungs analyzed 7 days post infection (dpi). (A) Gating strategy to identify live singlet lymphocytes from cells isolated from the lungs of mice for analyses. (B) Gating strategy to identify IL-10-producing T cells (with IL-10- T cells as control), and

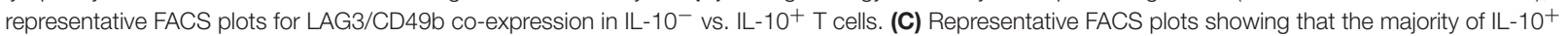
LAG3/CD49b co-expressing T cells in Nb-infected mouse lungs are CD4 ${ }^{+}$T cells, including both Foxp3 ${ }^{+}$Treg and Foxp3 ${ }^{-}$Tr1 cells. (D) Pie chart summarizing the proportion of Foxp3 ${ }^{+}$vs. Foxp3 ${ }^{-}$IL-10-producing LAG3/CD49b double positive CD4 ${ }^{+} \mathrm{T}$ cells. (E) Gating strategy identifying CD4 ${ }^{+} \mathrm{T}^{-}$cells that are Foxp3 ${ }^{-} \mathrm{IL}-10^{-}$, Foxp3 ${ }^{-} \mathrm{IL}-10^{+}$, Foxp3 $^{+} \mathrm{IL}-10^{-}$and Foxp3 ${ }^{+} \mathrm{IL}-10^{+}$. (F) Summary of percentage of LAG3/CD49b double positive population of Foxp3 ${ }^{-} \mathrm{IL}-10^{-}$, Foxp3 ${ }^{-} \mathrm{IL}-10^{+}$, Foxp3 ${ }^{+} \mathrm{IL}-10^{-}$, and Foxp3 ${ }^{+} \mathrm{IL}-10^{+}$CD4 ${ }^{+}$T cells. (G) Summary of gMFI of LAG3 and CD49b in Foxp3 ${ }^{+}$vs. Foxp3 $^{-}$IL-10-producing CD4 ${ }^{+} \mathrm{T}$ cells. $\mathrm{N}=4$. Data represent results of three experiments. ${ }^{\star \star \star} p \leq 0.001$, NS $=$ No significance, by non-parametric Mann-Whitney test. Data presented as Mean \pm S.E.M.

followed by Foxp3 ${ }^{-} \mathrm{CD}^{+} \mathrm{T}$ cells, while Foxp3 ${ }^{+} \mathrm{CD}^{+}$are a minority (Figure 3F). These data compared the composition of IL-10-producing $\mathrm{LAG}^{+} \mathrm{CD} 49 \mathrm{~b}^{+} \mathrm{T}$ cells in various murine models of pulmonary inflammatory diseases. Along with the model of parasitic infection shown in Figure 2, our data suggest that co-expression of LAG3 and CD49b marks all IL10 -producing $\mathrm{T}$ cell lineages in the pulmonary system, and relative abundance of the marked $\mathrm{T}$ cell subsets is dependent on the type of immune response as shown in the disease models.

\section{The Composition of LAG3 ${ }^{+}$CD49b ${ }^{+}$ IL-10-Producing T Cells Differs in Different Organs}

As discussed above, we demonstrated that co-expression of LAG3 and CD49b is a generic feature of IL-10-producing T cells in vivo in pulmonary tissues under multiple inflammatory conditions (Figures 2, 3). To determine whether this feature is applicable to IL-10-producing cells in other organs, we injected IL- $10^{\mathrm{GFP}} / \mathrm{Foxp} 3^{\mathrm{RFP}}$ dual reporter mice with an anti$\mathrm{CD} 3 \varepsilon$ antibody that has been shown to stimulate pronounced IL-10 production by $\mathrm{T}$ cells through TCR activation in vivo $(23,40)$. We analyzed IL-10-producing T cells in blood, lymph nodes (LN), lung, fat and small intestine, and found that coexpression of LAG3 and CD49b marked a portion of the IL-10producing $\mathrm{T}$ cells following TCR activation in vivo, which again included Foxp $3^{+} \mathrm{CD}^{+}{ }^{+}$, Foxp3 $3^{-} \mathrm{CD}^{+}$, and $\mathrm{CD} 8^{+} \mathrm{T}$ cell subsets (Figure 4A) in all organs analyzed. An interesting note is that the relative abundance of Foxp $3^{+} \mathrm{CD}^{+}, \mathrm{Foxp}^{-} \mathrm{CD} 4^{+}$, and $\mathrm{CD} 8^{+}$ subsets among the IL-10-producing $\mathrm{LAG}^{+} \mathrm{CD} 49 \mathrm{~b}^{+} \mathrm{T}$ cells vary significantly in different organs of the same mice (Figure 4B). Upon TCR activation in vivo, Foxp $3^{+} \mathrm{CD} 4^{+} \mathrm{T}$ cells are the major population that are IL- $10^{+} \mathrm{LAG}^{+} \mathrm{CD} 49 \mathrm{~b}^{+}$in the blood, lymph nodes and lungs, while $\mathrm{CD}^{+} \mathrm{T}$ cells are the majority of IL- $10^{+} \mathrm{LAG}^{+}{ }^{+} \mathrm{CD} 49 \mathrm{~b}^{+} \mathrm{T}$ cells in the perigonadal fat and small intestine (Figure 4B). These data suggest that co-expression of LAG3/CD49b marks all three IL-10-producing T cell subsets in 


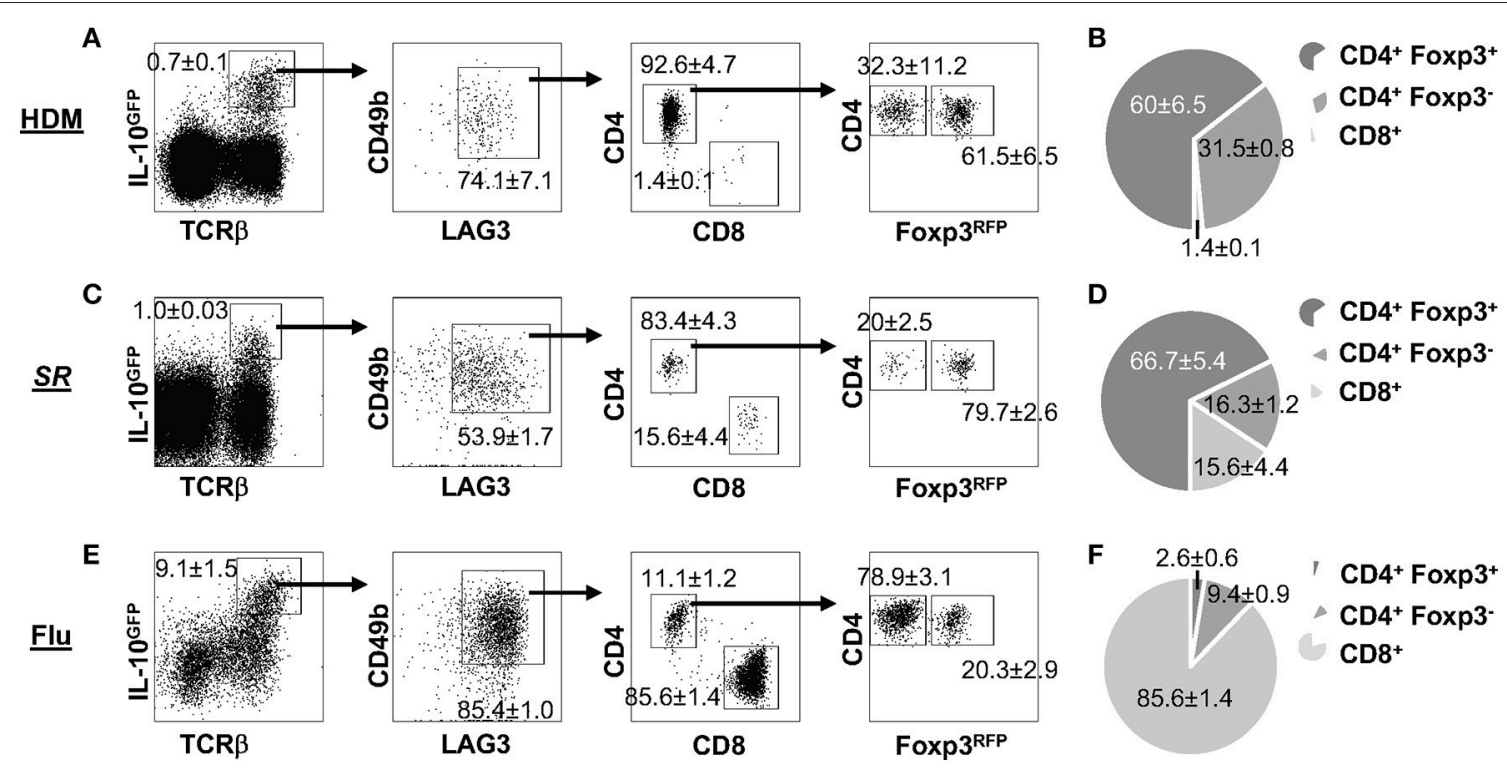

FIGURE 3 | Composition of IL-10-producing LAG3 ${ }^{+}$CD49b ${ }^{+}$T cells in lung inflammatory and infectious disease models. All experiments were performed using mice carrying the IL-10 GFP/Foxp3 ${ }^{R F P}$ dual reporter system, and cells were isolated from the lungs and gated on live singlets for analysis as shown in Figure $\mathbf{2 A}$. Representative FACS plots of LAG3/CD49b co-expression by IL-10-producing cells, and among these cells, ratio of CD4 ${ }^{+}$vs. CD8 ${ }^{+} \mathrm{T}_{\text {cells, and Foxp3 }}{ }^{-}$vs. Foxp3 ${ }^{+}$

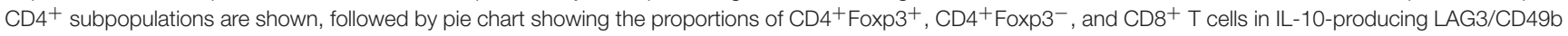
double positive T cell population. Mice were exposed intranasally to: (A,B) House dust mite (HDM) protein extract for 10 consecutive days, and analyzed $24 \mathrm{~h}$ post the last treatment; (C,D) Saccharopolyspora rectivirgula (SR) for 3 consecutive days every week for 4 weeks, and analyzed in the end of the fourth week; (E,F) influenza A (WSN) viruses, and analyzed 7 dpi. $N \geq 3$, combined from three independent experiments. Data presented as Mean \pm S.E.M.

multiple organs and the relative abundance of the Foxp $3^{+} \mathrm{CD} 4^{+}$, Foxp $3^{-} \mathrm{CD}^{+}$and $\mathrm{CD}^{+} \mathrm{T}$ cell subsets in IL-10-producing $\mathrm{LAG}^{+} \mathrm{CD} 49 \mathrm{~b}^{+} \mathrm{T}$ cells is dependent on the anatomical location of the cells.

\section{Human IL-10-Producing CD4 ${ }^{+}$and $\mathrm{CD}^{+}{ }^{+} \mathrm{T}$ Cells Exhibit a LAG3 ${ }^{+}$CD49b ${ }^{+}$Phenotype}

In murine models, we demonstrated that co-expression of LAG3 and CD49b marks IL-10-producing Foxp3 ${ }^{+} \mathrm{CD}^{+}$, Foxp $3^{-} \mathrm{CD}^{+}$, and $\mathrm{CD} 8^{+} \mathrm{T}$ cells under different inflammatory conditions in the lungs (Figures 2, 3), as well as in different organs when TCR is activated in vivo (Figure 4). To further determine whether different subsets of IL-10-producing T cells exhibit the shared feature of co-expression of LAG3 and CD49b in humans, we isolated $\mathrm{CD}^{+}$and $\mathrm{CD}^{+}{ }^{+} \mathrm{T}$ cells from human peripheral blood and cultured them under IL-10-inducing conditions. We found that as in the mouse, human IL-10producing $\mathrm{FOXP}^{+}{ }^{+} \mathrm{CD}^{+}{ }^{+} \mathrm{FOXP}^{+}{ }^{+} \mathrm{CD}^{+}$, and $\mathrm{CD}^{+}$subsets all up-regulated both LAG3 and CD49b expression, with a significant LAG3/CD49b double positive population (Figure 5).

\section{DISCUSSION}

Our data presented in this report demonstrated that, as previously reported (15), co-expression of LAG3 and CD49b identifies Foxp $3^{-}$IL-10 ${ }^{\text {high }}$ Tr1 cells, but that these markers are not exclusive for $\operatorname{Tr} 1$ cells in human and mouse. Furthermore, we find that the IL-10-producing $\mathrm{LAG}^{+}{ }^{+} \mathrm{CD} 49 \mathrm{~b}^{+} \mathrm{T}$ cell population is composed of $\mathrm{Foxp}^{+} \mathrm{CD}^{+}, \mathrm{Foxp}^{-} \mathrm{CD}^{+}$, and $\mathrm{CD} 8^{+}$ $\mathrm{T}$ cell subsets, and this composition varies depending on the disease conditions and anatomical locations of the cells. The importance of this work is emphasized by the need to specially identify Foxp $3^{-}$Tr1 cells, especially under clinical conditions, and our findings suggest that the use of LAG3 and CD49b should be combined with other markers to uniquely identify these cells.

Using $\operatorname{Tr} 1$ cell clones derived from human naïve $\mathrm{CD} 4^{+} \mathrm{T}$ cells and purified by an IL-10 secretion assay, Gagliani, Roncarolo and colleagues identified co-expression of LAG3, CD49b, and CD226 as cell a surface signature of IL-10-producing CD4 ${ }^{+} \mathrm{T}$ cells, and demonstrated that co-expression of LAG3 and CD49b is sufficient to distinguish Foxp $3^{-}$IL- $10^{\text {high }} \operatorname{Tr} 1$ cells from $\mathrm{T}$ helper and/or regulatory subsets that expressed lower levels of or no IL-10 in both mouse and human (15). However, it was recently reported that IL-10-producing $\mathrm{T}$ cells derived from human $\mathrm{CD} 4{ }^{+}$ memory T cells exhibit low levels of surface expression of LAG3 and CD49b (47), suggesting that the pattern of co-expression of LAG3 and CD49b may vary in human IL-10-producing CD4 ${ }^{+}$ $\mathrm{T}$ cells, which may be associated with whether they were derived from naïve precursors vs. memory cells. Indeed, it is clear that co-expression of LAG3 and CD49b can mark IL-10-producing Tr1-like cells, and serve to help eliminate those $\mathrm{T}$ cells lineages that are not capable of producing IL-10 for potential clinical interest. However, other non-Tr1-like IL-10-producing T cells can also co-express these markers. Whether co-expression of LAG3 and CD49b allows efficient recovery of IL-10 ${ }^{\text {high }} \mathrm{T}$ cells 


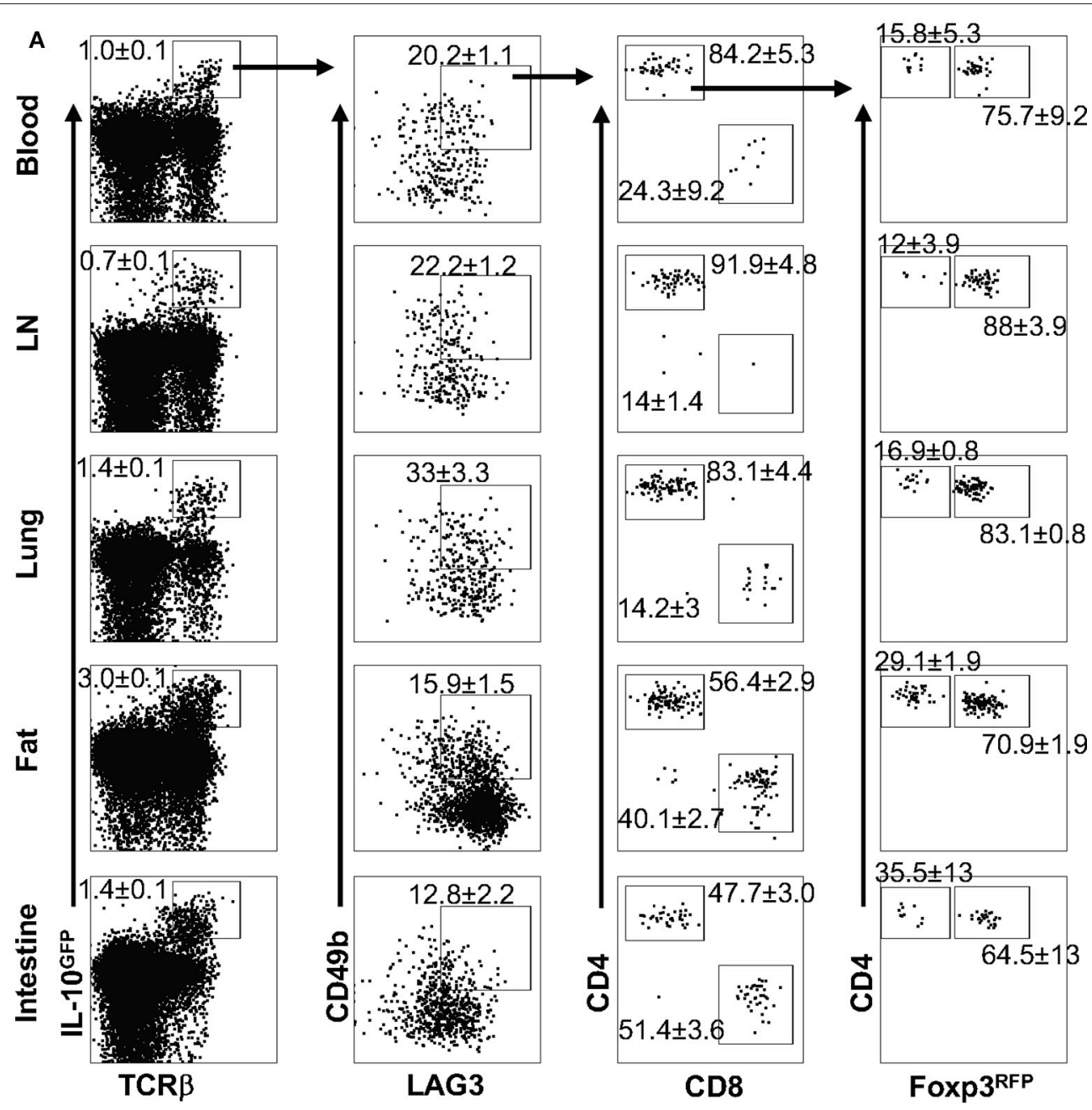

B

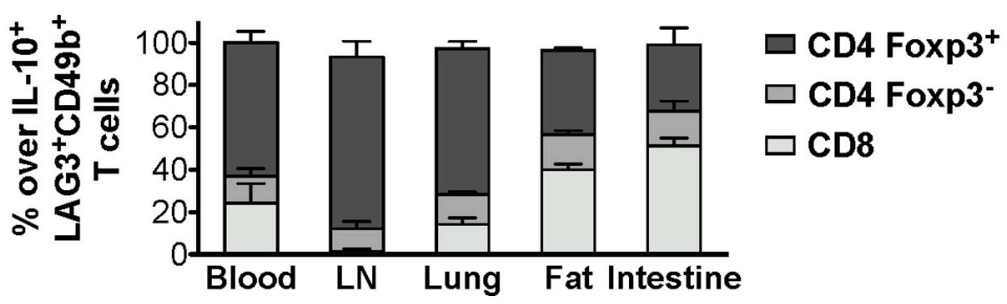

FIGURE 4 | Composition of IL-10-producing LAG3 ${ }^{+}$CD49b + T cells in various organs in vivo following TCR activation. Mice carrying the IL-10GFP/Foxp3RFP dual reporter system were injected with $\alpha \mathrm{CD} 3 \varepsilon$ antibody on day 0 and 2, and analyzed on day 4 . Live singlet cells from the indicated organs were gated for analysis. (A) Representative FACS plots showing LAG3/CD49b co-expression by IL-10-producing T cells, and among these cells, proportion of CD4 ${ }^{+}$vs. CD8 ${ }^{+} \mathrm{T}$ cells, and Foxp3 ${ }^{-}$vs. Foxp3 ${ }^{+} \mathrm{CD}_{4}^{+}$subpopulations. (B) Stacked bar chart summarizing the percentages of Foxp3 ${ }^{+} \mathrm{CD}^{+}$, Foxp3 ${ }^{-} \mathrm{CD}_{4}^{+}$, and $\mathrm{CD}^{+}{ }^{+}$cells in

IL-10-producing LAG3/CD49b double positive T cell population in the indicated organs. $N=3$. Data represent results of three experiments, and are presented as Mean \pm S.E.M.

may be dependent on the proportion of IL-10 high $\mathrm{T}$ cells that are co-expressing LAG3 and CD49b, which may differ depending on whether the relevant IL-10-producing cells had different origins and/or underwent different activation regimes.

Both LAG3 and CD49b can individually be up-regulated in activated $\mathrm{T}$ cells, regardless of their production of the anti-inflammatory IL-10 or pro-inflammatory cytokines
(31-33, 35-37). Co-expression of LAG3 and CD49b is more restricted to IL-10-producing subsets, as previously described in Foxp3 $3^{-} \mathrm{CD}^{+} \mathrm{T}$ cells (15). Our data here demonstrated that this is a generic feature of IL-10-producing cells, including Foxp3 ${ }^{-} \mathrm{CD}^{+}, \mathrm{Foxp}^{+} \mathrm{CD}^{+}$, and $\mathrm{CD}^{+}$subsets. The cooccurrence of $\mathrm{IL}-10$ production and $\mathrm{LAG} 3^{+} \mathrm{CD} 49 \mathrm{~b}^{+}$may be explained in two ways. The first explanation is that IL-10 

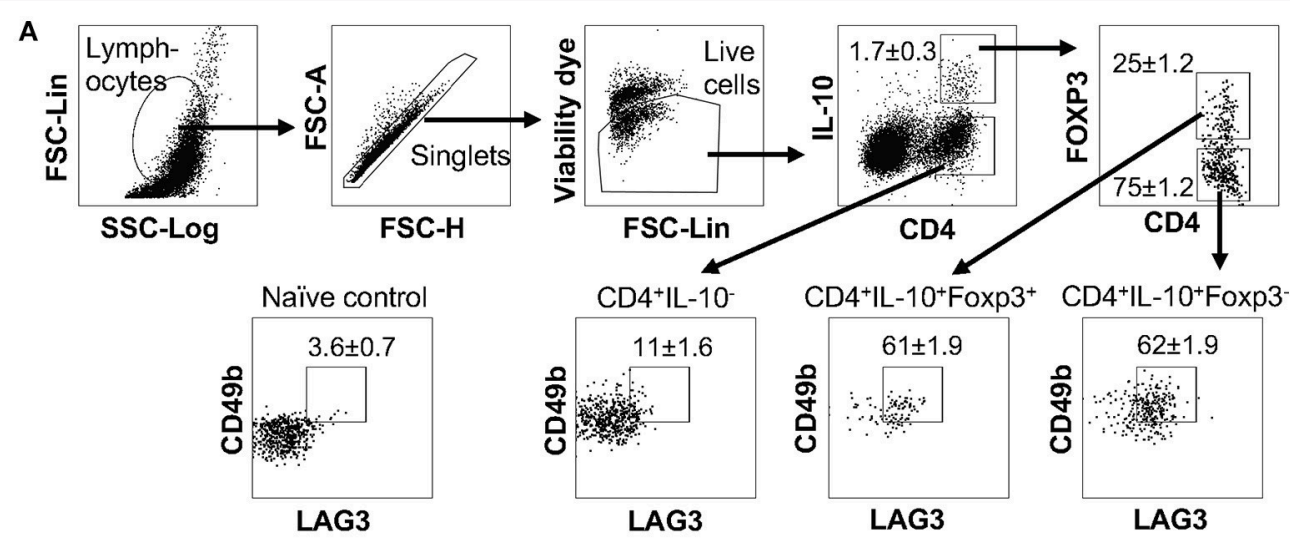

B
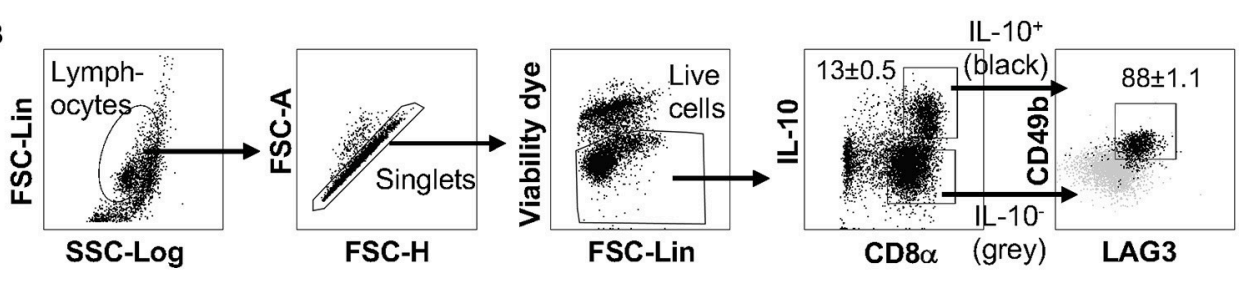

FIGURE 5 | Human IL-10-producing Treg, Tr1 and CD8 ${ }^{+}$T cells exhibit a LAG3 ${ }^{+} \mathrm{CD} 49 \mathrm{~b}^{+}$phenotype. CD4 ${ }^{+}$or $\mathrm{CD} 8^{+}$T cells isolated from human peripheral blood mononuclear cells were cultured under IL-10-inducing conditions; cells were stimulated and subjected to intracellular staining. (A) Representative FACS plots showing gating strategy to identify IL-10- CD4 ${ }^{+} \mathrm{T}$ cells and IL-10-producing FOXP3 ${ }^{+}$and FOXP3 ${ }^{-} \mathrm{CD}^{+}{ }^{+} \mathrm{T}$ cells and percentage of LAG3/CD49b double positive subset in these cells. Naiive $\mathrm{CD} 4^{+} \mathrm{T}$ cells were use as negative control to set the $L A G 3 / C D 49 \mathrm{~b}$ double positive gate. $N=4$. Data represent results of more than three independent experiments. (B) Representative plots showing gating strategy and LAG3/CD49b co-expression for IL-10-producing CD8 ${ }^{+}$T cells. Gray backgrounds show IL-10- CD8 ${ }^{+}$T cells as control. $N=6$. Data represent results of two independent experiments. Data presented as Mean \pm S.E.M.

stimulation through autocrine and/or paracrine may induce the expression of LAG3 and CD49b in the stimulated cells, therefore, IL-10-capturing T cells [cells detected by Roncarolo's group in ref (15)] exhibited high levels of LAG3/CD49b coexpression. This hypothesis would place IL-10 up-stream of LAG3 and CD49b expression, which is unlikely, as recent studies by Flavell and Huber's groups showed that the IL-10 receptor is dispensable for $\operatorname{Tr} 1$ cell differentiation, including the LAG3/CD49b double positive feature; instead, IL-10 receptor signaling is critical for maintaining the cell fate commitment and functional performance of the differentiated Tr1 cells (48). Therefore, it is more likely that LAG3 and CD49b signaling pathways function cooperatively to activate the expression of IL-10. This hypothesis is more reasonable, given our data that LAG3 and CD49b co-expression is a generic feature of IL-10 producing cells in multiple subsets. LAG3 is a structural homolog of the CD4 molecule, and can bind to MHC class II with higher affinity than $\operatorname{CD} 4(29,30)$. In unstimulated T cells, LAG3 is retained in the intracellular compartment and degraded in the lysosome. Upon T cell activation, LAG3 traffics from the lysosomal compartment to the cell surface through a protein kinase C (PKC) dependent pathway (49). CD49b is the integrin $\alpha 2$ subunit and plays a critical role in cell-cell interaction and adhesion (50). The CD49b pathway activates multiple downstream effector signaling pathways, among which is the RAS/MAPK signaling cascade $(51,52)$. We recently reported that the RAS/MAPK signaling pathway functioning downstream of the TCR is indispensable for IL-10 production by Foxp3 $3^{-} \mathrm{CD}^{+}$cells, through activation of the expression of the transcription factor interferon regulatory factor 4 (IRF4) (40). PKC can regulate RAS signaling to downstream effectors, and can activate MAPK signaling in both RAS-dependent and independent manners $(53,54)$. The interplay between PKC and RAS may regulate signals that connect LAG3 and CD49b downstream pathways, leading to up-regulation of IL-10. Given the complexity of these pathways, comprehensive understanding of the mechanism(s) underlying the co-expression of these markers with IL-10 will require significantly more in-depth analyses. Regardless of the mechanism, our findings indicate that LAG3/CD49b co-expression does not uniquely identify Foxp3$\operatorname{Tr} 1$ cells, but is a more general indicator of IL-10 production in $\mathrm{T}$ cell lineages.

Despite the shared feature of co-expression of LAG3 and CD 49 b by IL-10-producing Foxp $3^{+} \mathrm{CD}^{+}{ }^{+}$, Foxp $3^{-} \mathrm{CD} 4^{+}$, and $\mathrm{CD}^{+} \mathrm{T}$ cells, we also observed interesting discrepancies in the proportional composition of these three IL- $10^{\text {high }} \mathrm{T}$ cell subsets that are all LAG3/CD49b double positive in the lung mucosa of different pulmonary inflammatory disease models, as well as in different anatomical locations in the same mice upon TCR activation in vivo. For example, parasite infection $(\mathrm{Nb})$ and mite allergen (HDM) induced predominantly IL-10producing $\mathrm{LAG}^{+} \mathrm{CD}^{+} 9 \mathrm{~b}^{+} \mathrm{T}$ cells that are $\mathrm{CD} 4{ }^{+}$with very few that are $\mathrm{CD} 8^{+}$. In the $\mathrm{Nb}$ infection model, the majority of IL$10^{+} \mathrm{LAG}^{+} \mathrm{CD} 4 \mathrm{~b}^{+} \mathrm{CD}^{+}{ }^{+} \mathrm{T}$ cells are Foxp3 ${ }^{-} \mathrm{Tr} 1$ cells, while 
in HDM-exposed mice, Foxp $3^{+}$Treg cells are the majority. In the bacterial exposure $(S R)$ and viral infection (Flu) models, we observed an increased proportion of IL- $10^{+} \mathrm{LAG}^{+} \mathrm{CD}_{49} \mathrm{~b}^{+} \mathrm{T}$ cells that are $\mathrm{CD}^{+}$, which is the predominant population in the Flu model (Figure 3F). This discrepancy in the composition of IL-10-producing $\mathrm{LAG}^{+} \mathrm{CD}_{4} 9 \mathrm{~b}^{+} \mathrm{T}$ cells may be due to the difference of the microenvironment in which the IL-10producing cells are being induced. Factors that may affect the different composition of the IL- $10^{\text {high }} \mathrm{LAG}^{+} \mathrm{CD} 49 \mathrm{~b}^{+} \mathrm{T}$ cells may include the type of immune response, abundance and affinity of the TCR ligands, the cytokines induced and orchestrated by the stimuli, and the nutritional microenvironments that favor different subsets of the T cells. For example, type I IFN can facilitate the preferential induction of IL-10-producing effector $\mathrm{CD}^{+} \mathrm{T}$ cells through inducing and sustaining expression of the IRF4 and Blimp1 transcription factors (55). Type I interferon is significantly elevated during influenza infection (56) but much less so by HDM exposure (57). Another possible orchestrator could be the cytokine IL-27, which has been reported to be directly required for IL-10 induction in $\mathrm{CD}^{+} \mathrm{T}$ cells (58) and $\mathrm{CD}^{+}{ }^{+}$Foxp3 $^{-}$(59) but not CD4 ${ }^{+}$Foxp3 $^{+} \mathrm{T}$ cell subsets $(60)$. Transcription factors and their interacting molecular networks that exhibit differential functions for IL-10 induction in different $\mathrm{T}$ cell lineages might provide an answer as well. For example, Blimp-1 is indispensable for IL-10 induction in Foxp $3^{+}$and Foxp3 $^{-} \mathrm{CD}^{+} \mathrm{T}$ cells $(61,62)$, as well as in $\mathrm{CD}^{+} \mathrm{T}$ cells (63). AhR interaction with cMAF is critical in IL-10 induction in Foxp3 ${ }^{-} \operatorname{Tr} 1$ cells in response to an IL-27-supplemented environment, but is insufficient in inducing IL-10 production in Foxp3 ${ }^{+}$Treg cells under the same conditions (43); AhR expression was not critical in IL-10-producing $\mathrm{CD} 8^{+} \mathrm{T}$ cells either (64), suggesting that AhR signaling has a multifaceted function in regulating the level of IL-10 expression in different $\mathrm{T}$ cell lineages. A more comprehensive understanding of the T cellintrinsic molecular features that are shared or distinct among the IL-10-producing $\mathrm{CD}^{+}{ }^{+}$, Foxp $3^{-} \mathrm{CD} 4^{+}$and Foxp $3^{+} \mathrm{CD} 4^{+} \mathrm{T}$ cells awaits further investigation.

\section{REFERENCES}

1. Hawrylowicz CM, O'Garra, A. Potential role of interleukin-10-secreting regulatory T cells in allergy and asthma. Nat Rev Immunol. (2005) 5:271-83. doi: $10.1038 /$ nri1589

2. Kuhn R, Lohler J, Rennick D, Rajewsky K, Muller W. Interleukin10-deficient mice develop chronic enterocolitis. Cell (1993) 75:263-74. doi: 10.1016/0092-8674(93)80068-P

3. Gazzinelli RT, Wysocka M, Hieny S, Scharton-Kersten T, Cheever A, Kuhn $\mathrm{R}$, et al. In the absence of endogenous IL-10, mice acutely infected with Toxoplasma gondii succumb to a lethal immune response dependent on CD4+ T cells and accompanied by overproduction of IL-12, IFN-gamma and TNF-alpha. J Immunol. (1996) 157:798-805.

4. Li C, Corraliza I, Langhorne J. A defect in interleukin-10 leads to enhanced malarial disease in Plasmodium chabaudi chabaudi infection in mice. Infect Immun. (1999) 67:4435-42.

5. Ejrnaes M, Filippi CM, Martinic MM, Ling EM, Togher LM, Crotty S, et al. Resolution of a chronic viral infection after interleukin-10 receptor blockade. J Exp Med. (2006) 203:2461-72. doi: 10.1084/jem.20061462
Our data reported here demonstrate that co-expression of LAG3 and CD49b marks IL- $10^{\text {high }} \mathrm{T}$ cell subsets that are Foxp3 ${ }^{+} \mathrm{CD}^{+}$, Foxp3 $^{-} \mathrm{CD}^{+}$, or $\mathrm{CD}^{+}$in both human and mouse, and thus does not uniquely identify Foxp $3^{-} \operatorname{Tr} 1$ cells. However, this finding does not negate the feasibility of utilizing co-expression of LAG3 and CD49b in marking a broader range of immunosuppressive IL-10 $10^{\text {high }} \mathrm{T}$ cell populations that have potential therapeutic effects for clinical application. Further investigations are required to determine the levels of regulatory and pro-inflammatory cytokine production in the bulk $\mathrm{LAG}^{+}{ }^{+} \mathrm{CD} 49 \mathrm{~b}^{+} \mathrm{T}$ cells, and to determine and compare the ability of the Foxp $3^{+} \mathrm{CD} 4^{+}$, Foxp3 ${ }^{-} \mathrm{CD}^{+}$, and $\mathrm{CD}^{+}$subsets of the $\mathrm{LAG3}^{+} \mathrm{CD}^{+} 9 \mathrm{~b}^{+} \mathrm{T}$ cells in suppressing effector immunity and inflammation in vivo.

\section{AUTHOR CONTRIBUTIONS}

WH and AA conceived research, designed experiments, analyzed and interpreted data, and wrote the manuscript. WH, SS, and CC performed experiments; S-GZ contributed reagents and intellectual input.

\section{ACKNOWLEDGMENTS}

We thank A. Redko for animal care and L. Zhang for technical assistance; Dr. E. Tait Wojno for N. brasiliensis; and Drs. D. Topham, G. Whittaker, and M. Straus for influenza A virus. This work was supported in part by grants from the National Institutes of Health (AI120701, AI138570 and AI126814 to AA; AI129422 and AI138497 to AA and WH, and AI137822 to WH), a Careers in Immunology Fellowship from the American Association of Immunologists (to WH), a Pilot Grant from the Center for Experimental Infectious Disease Research (funded by NIH P30GM110760), the Faculty Development Program and an award from Competitive Research Programs of the Louisiana State University (to $\mathrm{WH}$ ).

6. Brooks DG, Trifilo MJ, Edelmann KH, Teyton L, McGavern DB, Oldstone MB. Interleukin-10 determines viral clearance or persistence in vivo. Nat Med. (2006) 12:1301-9. doi: 10.1038/nm1492

7. McGuirk P, McCann C, Mills KH. Pathogen-specific T regulatory 1 cells induced in the respiratory tract by a bacterial molecule that stimulates interleukin 10 production by dendritic cells: a novel strategy for evasion of protective T helper type 1 responses by Bordetella pertussis. J Exp Med. (2002) 195:221-31. doi: 10.1084/jem.20011288

8. Siewe L, Bollati-Fogolin M, Wickenhauser C, Krieg T, Muller W, Roers A. Interleukin-10 derived from macrophages and/or neutrophils regulates the inflammatory response to LPS but not the response to CpG DNA. Eur J Immunol. (2006) 36:3248-55. doi: 10.1002/eji.200636012

9. Zhang X, Majlessi L, Deriaud E, Leclerc C, Lo-Man R. Coactivation of Syk kinase and MyD88 adaptor protein pathways by bacteria promotes regulatory properties of neutrophils. Immunity (2009) 31:761-71. doi: 10.1016/j.immuni.2009.09.016

10. Wang S, Xia P, Chen Y, Qu Y, Xiong Z, Ye B, Du Y, et al. Regulatory innate lymphoid cells control innate intestinal inflammation. Cell (2017) 171:201-16 e18. doi: 10.1016/j.cell.2017.07.027 
11. Yanaba K, Bouaziz JD, Haas KM, Poe JC, Fujimoto M, Tedder TF. A regulatory $\mathrm{B}$ cell subset with a unique $\mathrm{CD} 1 \mathrm{dhiCD} 5+$ phenotype controls $\mathrm{T}$ cell-dependent inflammatory responses. Immunity (2008) 28:639-50. doi: 10.1016/j.immuni.2008.03.017

12. Roncarolo MG, Gregori S, Battaglia M, Bacchetta R, Fleischhauer K, Levings MK. Interleukin-10-secreting type 1 regulatory $\mathrm{T}$ cells in rodents and humans. Immunol Rev. (2006) 212:28-50. doi: 10.1111/j.0105-2896.2006.00420.x

13. Maynard CL, Harrington LE, Janowski KM, Oliver JR, Zindl CL, Rudensky AY, et al. Regulatory $\mathrm{T}$ cells expressing interleukin 10 develop from Foxp3+ and Foxp3- precursor cells in the absence of interleukin 10. Nat Immunol. (2007) 8:931-41. doi: 10.1038/ni1504

14. Noble A, Giorgini A, Leggat JA. Cytokine-induced IL-10-secreting CD8 T cells represent a phenotypically distinct suppressor T-cell lineage. Blood (2006) 107:4475-83. doi: 10.1182/blood-2005-10-3994

15. Gagliani N, Magnani CF, Huber S, Gianolini ME, Pala M, Licona-Limon P, et al. Coexpression of CD49b and LAG-3 identifies human and mouse T regulatory type 1 cells. Nat Med. (2013) 19:739-46. doi: 10.1038/nm.3179

16. Roncarolo MG, Gregori S, Bacchetta R, Battaglia M. Tr1 cells and the counter-regulation of immunity: natural mechanisms and therapeutic applications. Curr Top Microbiol Immunol. (2014) 380:39-68. doi: 10.1007/978-3-662-43492-5_3

17. O'Garra A, Barrat FJ, Castro AG, Vicari A, Hawrylowicz C. Strategies for use of IL-10 or its antagonists in human disease. Immunol Rev. (2008) 223:114-31. doi: 10.1111/j.1600-065X.2008.00635.x

18. O'Garra A, Vieira P. Regulatory T cells and mechanisms of immune system control. Nat Med. (2004) 10:801-5. doi: 10.1038/nm0804-801

19. Sakaguchi S, Yamaguchi T, Nomura T, Ono M. Regulatory T cells and immune tolerance. Cell (2008) 133:775-87. doi: 10.1016/j.cell.2008.05.009

20. Sun J, Madan R, Karp CL, Braciale TJ. Effector $T$ cells control lung inflammation during acute influenza virus infection by producing IL-10. Nat Med. (2009) 15:277-84. doi: 10.1038/nm.1929

21. Okamura T, Fujio K, Sumitomo S, Yamamoto K. Roles of LAG3 and EGR2 in regulatory T cells. Ann Rheum Dis. (2012) 2:i96-100. doi: 10.1136/annrheumdis-2011-200588

22. Gol-Ara M, Jadidi-Niaragh F, Sadria R, Azizi G, Mirshafiey A. The role of different subsets of regulatory $\mathrm{T}$ cells in immunopathogenesis of rheumatoid arthritis. Arthritis (2012) 2012:805875. doi: 10.1155/2012/805875

23. Huber S, Gagliani N, Esplugues E, O’Connor W Jr., Huber FJ, Chaudhry A, et al. Th17 cells express interleukin-10 receptor and are controlled by Foxp3(-) and Foxp3+ regulatory CD4+ $\mathrm{T}$ cells in an interleukin-10-dependent manner. Immunity (2011) 34:554-65. doi: 10.1016/j.immuni.2011.01.020

24. Ahangarani RR, Janssens W, VanderElst L, Carlier V, VandenDriessche $\mathrm{T}$, Chuah $\mathrm{M}$, et al. In vivo induction of type 1-like regulatory $\mathrm{T}$ cells using genetically modified B cells confers long-term IL-10-dependent antigen-specific unresponsiveness. J Immunol. (2009) 183:8232-43. doi: 10.4049/jimmunol.0901777

25. Volz T, Skabytska Y, Guenova E, Chen KM, Frick JS, Kirschning CJ, et al. Nonpathogenic bacteria alleviating atopic dermatitis inflammation induce IL10-producing dendritic cells and regulatory Tr1 cells. J Invest Dermatol. (2014) 134:96-104. doi: 10.1038/jid.2013.291

26. Bohm L, Maxeiner J, Meyer-Martin H, Reuter S, Finotto S, Klein $\mathrm{M}$, et al. IL-10 and regulatory $\mathrm{T}$ cells cooperate in allergen-specific immunotherapy to ameliorate allergic asthma. J Immunol. (2015) 194:887-97. doi: 10.4049/jimmunol.1401612

27. Mobs C, Slotosch C, Loffler H, Jakob T, Hertl M, Pfutzner W. Birch pollen immunotherapy leads to differential induction of regulatory $\mathrm{T}$ cells and delayed helper T cell immune deviation. J Immunol. (2010) 184:2194-203. doi: 10.4049/jimmunol.0901379

28. Fitzgerald DC, Zhang GX, El-Behi M, Fonseca-Kelly Z, Li H, Yu S, et al. Suppression of autoimmune inflammation of the central nervous system by interleukin 10 secreted by interleukin 27-stimulated T cells. Nat Immunol. (2007) 8:1372-9. doi: 10.1038/ni1540

29. Huard B, Prigent P, Tournier M, Bruniquel D, Triebel F. CD4/major histocompatibility complex class II interaction analyzed with CD4- and lymphocyte activation gene-3 (LAG-3)-Ig fusion proteins. Eur J Immunol. (1995) 25:2718-21. doi: 10.1002/eji.1830250949

30. Huard B, Mastrangeli R, Prigent P, Bruniquel D, Donini S, El-Tayar N, et al. Characterization of the major histocompatibility complex class II binding site on LAG-3 protein. Proc Natl Acad Sci USA. (1997) 94:5744-9. doi: $10.1073 /$ pnas.94.11.5744

31. Okamura T, Fujio K, Shibuya M, Sumitomo S, Shoda H, Sakaguchi $\mathrm{S}$, et al. CD4+CD25-LAG3+ regulatory $\mathrm{T}$ cells controlled by the transcription factor Egr-2. Proc Natl Acad Sci USA. (2009) 106:13974-9. doi: $10.1073 /$ pnas.0906872106

32. Triebel F, Jitsukawa S, Basixeras E, Roman-Roman S, Genevee C, ViegasPequignot E, et al. LAG-3, a novel lymphocyte activation gene closely related to CD4. J Exp Med. (1990) 171:1393-405. doi: 10.1084/jem.171.5.1393

33. Camisaschi C, Casati C, Rini F, Perego M, De Filippo A, Triebel $F$, et al. LAG-3 expression defines a subset of $\mathrm{CD} 4(+) \mathrm{CD} 25$ (high)Foxp3(+) regulatory $\mathrm{T}$ cells that are expanded at tumor sites. J Immunol. (2010) 184:6545-51. doi: 10.4049/jimmunol.09 03879

34. Arase H, Saito T, Phillips JH, Lanier LL. Cutting edge: the mouse NK cell-associated antigen recognized by DX5 monoclonal antibody is CD49b (alpha 2 integrin, very late antigen-2). J Immunol. (2001) 167:1141-4. doi: 10.4049/jimmunol.167.3.1141

35. Charbonnier LM, van Duivenvoorde LM, Apparailly F, Cantos C, Han WG, Noel D, et al. Immature dendritic cells suppress collagen-induced arthritis by in vivo expansion of $\mathrm{CD} 49 \mathrm{~b}+$ regulatory $\mathrm{T}$ cells. J Immunol. (2006) 177:3806-13. doi: 10.4049/jimmunol.177.6.3806

36. Boisvert M, Chetoui N, Gendron S, Aoudjit F. Alpha2beta1 integrin is the major collagen-binding integrin expressed on human Th17 cells. Eur J Immunol. (2010) 40:2710-9. doi: 10.1002/eji.201040307

37. Kassiotis G, Gray D, Kiafard Z, Zwirner J, Stockinger B. Functional specialization of memory Th cells revealed by expression of integrin CD49b. J Immunol. (2006) 177:968-75. doi: 10.4049/jimmunol.177.2.968

38. Kamanaka M, Kim ST, Wan YY, Sutterwala FS, Lara-Tejero M, Galan JE, et al. Expression of interleukin-10 in intestinal lymphocytes detected by an interleukin-10 reporter knockin tiger mouse. Immunity (2006) 25:941-52. doi: 10.1016/j.immuni.2006.09.013

39. Wan YY, Flavell RA. Identifying Foxp3-expressing suppressor $\mathrm{T}$ cells with a bicistronic reporter. Proc Natl Acad Sci USA. (2005) 102:5126-31. doi: $10.1073 /$ pnas.0501701102

40. Huang W, Solouki S, Koylass N, Zheng SG, August A. ITK signalling via the Ras/IRF4 pathway regulates the development and function of $\operatorname{Tr} 1$ cells. Nat Commun. (2017) 8:15871. doi: 10.1038/ncomms15871

41. Simonian PL, Roark CL, Wehrmann F, Lanham AK, F. Diaz del Valle, Born WK, et al. Th17-polarized immune response in a murine model of hypersensitivity pneumonitis and lung fibrosis. J Immunol. (2009) 182:65765. doi: 10.4049/jimmunol.182.1.657

42. Huang W, Qi Q, Hu J, Huang F, Laufer TM, August A. Dendritic cellMHC class II and Itk regulate functional development of regulatory innate memory CD4+ T cells in bone marrow transplantation. J Immunol. (2014) 192:3435-3441. doi: 10.4049/jimmunol.1303176

43. Apetoh L, Quintana FJ, Pot C, Joller N, Xiao S, Kumar D, et al. The aryl hydrocarbon receptor interacts with c-Maf to promote the differentiation of type 1 regulatory T cells induced by IL-27. Nat Immunol. (2010) 11:854-61. doi: $10.1038 /$ ni. 1912

44. Chen F, Liu Z, Wu W, Rozo C, Bowdridge S, Millman A, et al. An essential role for $\mathrm{TH} 2$-type responses in limiting acute tissue damage during experimental helminth infection. Nat Med. (2012) 18:260-6. doi: 10.1038/ nm. 2628

45. Hawrylowicz CM. Regulatory T cells and IL-10 in allergic inflammation. J Exp Med. (2005) 202:1459-63. doi: 10.1084/jem.20052211

46. Gudmundsson G, Bosch A, Davidson BL, Berg DJ, Hunninghake GW. Interleukin-10 modulates the severity of hypersensitivity pneumonitis in mice. Am J Respir Cell Mol Biol. (1998) 19:812-8. doi: 10.1165/ajrcmb.19.5.3153

47. White AM, Wraith DC. Tr1-Like T Cells - an enigmatic regulatory T cell lineage. Front Immunol. (2016) 7:355. doi: 10.3389/fimmu.2016.00355

48. Brockmann L, Gagliani N, Steglich B, Giannou AD, Kempski J, Pelczar P, et al. IL-10 Receptor signaling is essential for TR1 cell function in vivo. J Immunol. (2017) 198:1130-41. doi: 10.4049/jimmunol.1601045

49. Bae J, Lee SJ, Park CG, Lee YS, Chun T. Trafficking of LAG-3 to the surface on activated T cells via its cytoplasmic domain and protein kinase $\mathrm{C}$ signaling. $J$ Immunol. (2014) 193:3101-12. doi: 10.4049/jimmunol.1401025 
50. Carter WG, Wayner EA, Bouchard TS, Kaur P. The role of integrins alpha 2 beta 1 and alpha 3 beta 1 in cell-cell and cell-substrate adhesion of human epidermal cells. J Cell Biol. (1990) 110:1387-404. doi: 10.1083/jcb.110.4.1387

51. Mainiero F, Gismondi A, Soriani A, Cippitelli M, Palmieri G, et al. Integrin-mediated ras-extracellular regulated kinase (ERK) signaling regulates interferon gamma production in human natural killer cells. J Exp Med. (1998) 188:1267-75. doi: 10.1084/jem.188.7.1267

52. Guo W, Giancotti FG. Integrin signalling during tumour progression. Nat Rev Mol Cell Biol. (2004) 5:816-26. doi: 10.1038/nrm1490

53. Rusanescu G, Gotoh T, Tian X, Feig LA. Regulation of Ras signaling specificity by protein kinase C. Mol Cell Biol. (2001) 21:2650-8. doi: 10.1128/MCB.21.8.2650-2658.2001

54. Ueda Y, Hirai S, Osada S, Suzuki A, Mizuno K, Ohno S. Protein kinase $\mathrm{C}$ activates the MEK-ERK pathway in a manner independent of Ras and dependent on Raf. J Biol Chem. (1996) 271:23512-9. doi: 10.1074/jbc.271.38.23512

55. Jiang L, Yao S, Huang S, Wright J, Braciale TJ, Sun J. Type I IFN signaling facilitates the development of IL-10-producing effector CD8(+) T cells during murine influenza virus infection. Eur J Immunol. (2016) 46:2778-88. doi: 10.1002/eji.201646548

56. Di Domizio J, Blum A, Gallagher-Gambarelli M, Molens JP, Chaperot L, Plumas J. TLR7 stimulation in human plasmacytoid dendritic cells leads to the induction of early IFN-inducible genes in the absence of type I IFN. Blood (2009) 114:1794-802. doi: 10.1182/blood-2009-04-216770

57. Webb LM, Lundie RJ, Borger JG, Brown SL, Connor LM, Cartwright AN, et al. Type I interferon is required for T helper (Th) 2 induction by dendritic cells. EMBO J. (2017) 36:2404-18. doi: 10.15252/embj.201695345

58. Perona-Wright G, Kohlmeier JE, Bassity E, Freitas TC, Mohrs K, Cookenham $\mathrm{T}$, et al. Persistent loss of IL-27 responsiveness in CD8+ memory T cells abrogates IL-10 expression in a recall response. Proc Natl Acad Sci USA. (2012) 109:18535-40. doi: 10.1073/pnas.1119133109

59. Pot C, Jin H, Awasthi A, Liu SM, Lai CY, Madan R, et al. Cutting edge: IL-27 induces the transcription factor c-Maf, cytokine IL-21, and the costimulatory receptor ICOS that coordinately act together to promote differentiation of IL-10-producing Tr1 cells. J Immunol. (2009) 183:797-801. doi: 10.4049/jimmunol.0901233

60. Do J, Kim D, Kim S, Valentin-Torres A, Dvorina N, Jang E, et al. Tregspecific IL-27Ralpha deletion uncovers a key role for IL-27 in Treg function to control autoimmunity. Proc Natl Acad Sci USA. (2017) 114:10190-5. doi: 10.1073/pnas.1703100114

61. Cretney E, Xin A, Shi W, Minnich M, Masson F, Miasari M, et al. The transcription factors Blimp-1 and IRF4 jointly control the differentiation and function of effector regulatory T cells. Nat Immunol. (2011) 12:304-11. doi: 10.1038/ni.2006

62. Neumann C, Heinrich F, Neumann K, Junghans V, Mashreghi MF, Ahlers J, et al. Role of Blimp-1 in programing Th effector cells into IL-10 producers. J Exp Med. (2014) 211:1807-19. doi: 10.1084/jem.201 31548

63. Sun J, Dodd H, Moser EK, Sharma R, Braciale TJ. CD4+ T cell help and innate-derived IL-27 induce Blimp-1-dependent IL-10 production by antiviral CTLs. Nat Immunol. (2011) 12:327-34. doi: 10.1038/ ni.1996

64. Trandem K, Zhao J, Fleming E, Perlman S. Highly activated cytotoxic CD8 T cells express protective IL-10 at the peak of coronavirus-induced encephalitis. J Immunol. (2011) 186:3642-52. doi: 10.4049/jimmunol.10 03292

Conflict of Interest Statement: The authors declare that the research was conducted in the absence of any commercial or financial relationships that could be construed as a potential conflict of interest.

Copyright (C) 2018 Huang, Solouki, Carter, Zheng and August. This is an open-access article distributed under the terms of the Creative Commons Attribution License (CC $B Y)$. The use, distribution or reproduction in other forums is permitted, provided the original author(s) and the copyright owner(s) are credited and that the original publication in this journal is cited, in accordance with accepted academic practice. No use, distribution or reproduction is permitted which does not comply with these terms. 